Jurnal Laut Khatulistiwa, Vol. 3. No. 2 (Juli, 2020). Hal. 61-68.

ISSN : 2614-6142 (Printed), 2614-8005 (Online)

http://jurnal.untan.ac.id/index.php/lk

JURNAL LAUT

KHATULISTIWA

\title{
Struktur Komunitas Mikroalga Epifit Berasosiasi Pada Sargassum sp. Di Perairan Desa Sepempang Kabupaten Natuna
}

\section{The Community Structure Of Epiphytic Microalgae Associated With Sargassum sp. On The Waters Of The Sepempang Village Natuna Regency}

\author{
Meilinda Tria Tarigas $^{1 *}$, Apriansyah ${ }^{1}$, Ikha Safitri ${ }^{1}$ \\ ${ }^{1}$ Laboratorium Ilmu Kelautan, FMIPA, Universitas Tanjunpura, Pontianak, Indonesia \\ ${ }^{*}$ E-mail : meilindatria05@gmail.com
}

Received : 5 AFebuari 2020; Accepted : 13 Mei 2020

Published : 30 Juni 2020 (C) Author(s) 2020. This article is open access

\begin{abstract}
Epiphytic microalgae is an organism that can live attaching to the substrate such as macroalgae. Epiphytes have an important role in increasing primary productivity and aquatic bioindicators. The purpose of this study was to determine the community structure of associated epiphytic microalgae in Sargassum sp. in Sepempang Village waterway, Natuna Regency. The study was conducted in January-June 2019. The sampling of epiphytic microalgae was carried out through in situ. The study was conducted by survey method and the determination of sampling stations by purposive sampling. The macroalgae sampling location consisted of 4 stations with different environmental bases. The result of epiphytic microalgae identification consist of 8 classes, 36 orders, 50 families and 65 genera. The class of bacillariophyceae (diatoms) was found dominantly with the percentage of abundance (72.67\%), where the abundance of diatom pennate (81.69\%) and diatom centric (18.31\%). The dominant genera that found were Navicula, Nitzschia, Synedra, Cocconeis and Pinnularia. Diversity index (H ') ranges from 3.04-3.18, uniformity index $(E)$ ranges from 0.77-0.83, dominance index $(C)$ ranges from 0.060.07 , and Sorensen Similarity index (ISS) ranges from $75.55-87.80 \%$.
\end{abstract}

Keywords : Microalgae, Sargassum sp, Community Structure

\begin{abstract}
Abstrak
Mikroalga epifit merupakan organisme yang dapat hidup menempel pada substrat seperti makroalga. Epifit memiliki peran penting dalam meningkatkan produktivitas primer dan bioindikator perairan. Tujuan dari penelitian ini untuk mengetahui struktur komunitas mikroalga epifit berasosiasi pada Sargassum sp. di perairan Desa Sepempang, Kabupaten Natuna. Penelitian dilaksanakan pada bulan januari - juni 2019. Pengambilan sampel mikroalga epifit dilaksanakan secara in situ. Penelitian dilakukan dengan metode survey dan penentuan stasiun pengambilan sampel secara purposive sampling. Lokasi pengambilan sampel makroalga terdiri dari 4 stasiun dengan rona lingkungan yang berbeda. Hasil identifikasi mikroalga epifit terdiri dari 8 kelas, 36 ordo, 50 famili dan 65 genus. Kelas bacillariophyceae (diatom) ditemukan dominan dengan persentase kelimpahan (72.67\%), dimana kelimpahan diatom pennate $(81.69 \%)$ dan diatom sentris (18.31\%). Genus yang dominan ditemukan adalah Navicula, Nitzschia, Synedra, Cocconeis dan Pinnularia. Nilai indeks keanekaragaman ( $\left.\mathrm{H}^{\prime}\right)$ berkisar 3.04-3.18, indeks keseragaman (E) berkisar 0.770.83, indeks dominasi (C) berkisar 0.06-0.07, dan nilai indeks Similaritas Sorensen (ISS) berkisar 75.55$87.80 \%$
\end{abstract}

Kata kunci : Mikroalga, Sargassum sp, Struktur Komunitas

\section{Pendahuluan}

Kabupaten Natuna terletak di Provinsi Kepulauan Riau dengan luas wilayah sebesar $224.684,59 \mathrm{~km}^{2}$ dan 99,11\% wilayah merupakan perairan laut (BPS Kabupaten Natuna, 2018). Perairan Kabupaten Natuna memiliki potensi sumberdaya hayati laut seperti terumbu karang, lamun, mangrove 
Jurnal Laut Khatulistiwa, Vol. 3. No. 2 (Juli, 2020). Hal. 61-68.

(Pigawati, 2005), dan makroalga (BP3SP, 2008; BPS Kabupaten Natuna, 2016). Desa Sepempang termasuk dalam wilayah Kabupaten Natuna juga memiliki potensi makroalga seperti E. cottonii, Caulerpa sp., Sargassum sp., dan Padina sp. Makroalga jenis Sargasum sp. ditemukan dengan ketersediaan yang melimpah di daerah pesisir Desa Sepempang dan belum di manfaatkan secara optimal. Sargassum sp. dapat tumbuh pada perairan tropis maupun subtropis (Mattio and Payri, 2010) dan dapat dimanfaatkan sebagai tempat tinggal atau substrat berbagai jenis biota laut. Epifit merupakan organisme renik yang dapat hidup menempel pada substrat (Martoni et al., 2016), seperti makroalga (Rindy and Guary, 2004; Kersel et al., 2011; ElDin et al., 2015; Al-Harbi and Affan, 2016; AlHarbi, 2017). Salah satu jenis organisme epifit tersebut adalah mikroalga. Mikroalga epifit berperan penting dalam peningkatan produktivitas primer perairan (Rosada et al., 2017) dan memiliki komponen aktif yang dapat dimanfaatkan dalam bidang industri, farmasi dan perikanan (Rafaelina et al., 2016). Keberadaan mikroalga epifit juga dapat dimanfaatkan sebagai bioindikator kualitas perairan (Rosada et al., 2017). Pengetahuan mengenai pontesi mikroalga epifit dalam setiap bidang menjadi alasan penting untuk dilakukan penelitian mengenai keanekaragaman mikroalga epifit di Perairan Desa Sepempang Kabupaten Natuna. Tujuan dari penelitian ini yaitu untuk mengetahui struktur komunitas mikroalga epifit berasosiasi pada Sargassum sp. di Perairan Desa Sepempang, Kabupaten Natuna.

\section{Metode}

\subsection{Waktu dan Lokasi Penelitian}

Penelitian dilaksanakan pada bulan Januari - Juni 2019. Pengambilan sampel mikroalga epifit dilaksanakan secara in situ pada bulan Januari di perairan Desa Sepempang, Kabupaten Natuna (Gambar 1). Pengamatan dan identifikasi jenis mikroalga epifit dilakukan di Laboratorium Ilmu Kelautan, Fakultas Matematiaka dan Ilmu Pengetahuan Alam, Universitas Tanjungpura, Pontianak.

Penelitian ini dilakukan dengan metode survey dan penentuan stasiun pengambilan sampel secara purposive sampling. Lokasi pengambilan sampel makroalga Sargassum sp. terdiri dari 4 stasiun. Stasiun I merupakan zona dekat dengan dermaga, stasiun II zona yang berada dekat dengan daerah pemukiman, stasiun III adalah zona yang dekat dengan budidaya ikan, dan stasiun IV merupakandaerah yang jauh dari aktifitas manusia.

Sampel makroalga Sargassum sp. diambil sebanyak tiga kali ulangan pada setiap lokasi yang telah ditentukan. Pengambilan sampel dilakukan pada daerah yang masih dipengaruhi oleh pasang surut dan pada kedalaman tertentu (El-Din et al., 2015) dari pertama kali ditemukannya makroalga. Selanjutnya, sampel makroalga dimasukkan ke dalam kantong plastik sampel dan disimpan dalam cool box.

\subsection{Pemisahan Mikroalga Epifit}

Makroalga ditimbang sebanyak $5 \mathrm{~g}$ untuk masing-masing pengulangan, kemudian diserut seluruh permukaan sampel dengan menggunkan pisau. Setelah itu, hasil serutan dimasukkan ke dalam botol falkon dan ditambah akuades hingga volume total $20 \mathrm{~mL}$ untuk mendapatkan epifit terkonsentrat. Langkah selanjutnya, sampel epifit ditambah formalin $4 \%$ sebanyak 3 tetes untuk pengawetan sampel. Perhitungan jumlah mikroalga epifit dilakukan dengan menggunakan mikroskop dan hasilnya dinyatakan dalam individu per gram berat basah makroalga inang Sargassum sp.

\subsection{Analisis Data}

Nilai kelimpahan (K) mikroalga epifit dihitung menggunakan rumus :

$$
K=\frac{\mathrm{Vr}}{\mathrm{Vo}_{\mathrm{o}}} \times \frac{1}{\mathrm{~W}} \times n
$$

Dimana $\mathrm{K}$ merupakan kelimpahan epifit (ind/5g berat basah inang), $\mathrm{Vr}$ adalah volume konsentrat dalam botol sampel (20 mL), Vo adalah volume satuan tetes air sampel $(1 \mathrm{~mL})$, $\mathrm{W}$ adalah berat basah makroalga inang ( $5 \mathrm{~g})$, 
Jurnal Laut Khatulistiwa, Vol. 3. No. 2 (Juli, 2020). Hal. 61-68.

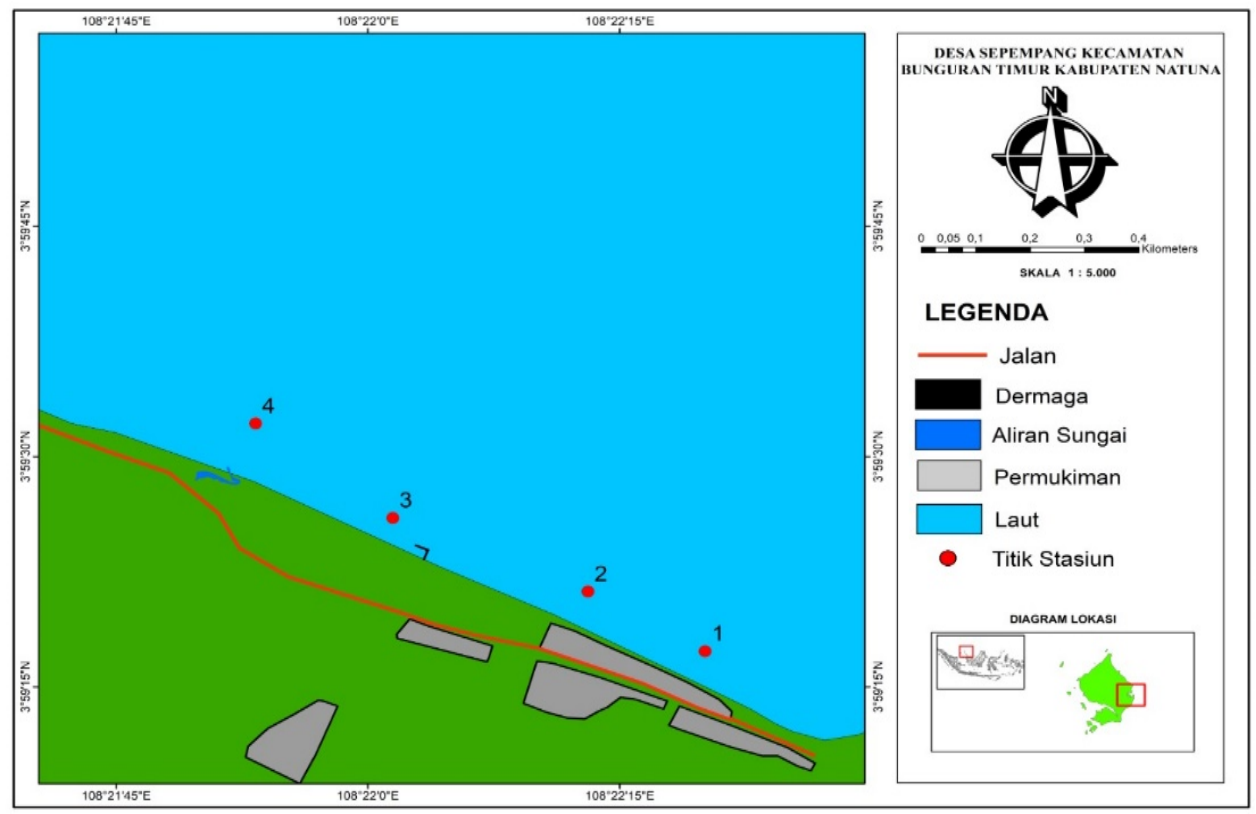

Gambar 1. Peta lokasi penelitian

dan $n$ adalah jumlah mikroalga epifi yang tercacah.

Perhitungan kelimpahan relatif (KR) mikroalga epifit menggunakan rumus :

$$
K R=\frac{\mathrm{K} \text { suatu jenis }}{\mathrm{K} \text { total }} \times 100 \%
$$

Dimana KR adalah kelimpahan relatif (\%) dan $\mathrm{K}$ dalah kelimpahan mikroalga epifit.

Indeks keanekaragaman $\left(\mathrm{H}^{\prime}\right)$ mikroalga epifit dihitung menggunakan rumus :

$$
\mathrm{H}^{\prime}=-\sum_{\mathrm{i}=1}^{\mathrm{n}} p i \ln p i
$$

Dimana $\mathrm{H}^{\prime}$ adalah indeks keanekaragaman, pi adalah propisi spesies ke-i, ln adalah logaritma nature dan $\Sigma \mathrm{ni} / \mathrm{N}$ adalah perbandingan jumlah individu suatu jenis dengan jumlah individu keseluruhan jenis. Menurut Odum (1993), nilai $\mathrm{H}^{\prime}<1$ berarti tingkat keanekaragaman mikroalga epifit di suatu perairan tergolong rendah, nilai $1<\mathrm{H}^{\prime}<3$ tingkat keanekaragaman masuk dalam kategori sedang, dan $\mathrm{H}^{\prime}>3$ tingkat keanekaragaman tergolong katergori tinggi.

Indeks keseragaman (E) mikroalga epifit dihitung menggunakan rumus :

$$
E=\frac{\mathrm{H}^{\prime}}{\mathrm{H} \max }
$$

E adalah indeks keseragaman, $\mathrm{H}^{\prime}$ adalah indeks keanekaragaman Shannon-Wiener, $\mathrm{H}_{\max }$ adalah keanekaragaman maksimum $(\ln \mathrm{S})$ dan $S$ adalah banyaknya genus yang ditemukan. Nilai indeks keseragaman berkisar antara 0-1, jika nilai $\mathrm{E}$ mendekati 0 maka sebaran individu antar jenis tidak seragam dan apabila nilai E mendekati 1 maka sebaran individu antar jenis dalam kategori seragam (Odum, 1993)

Indeks dominansi (C) mikroalga epifit dihitung menggunakan rumus (Odum, 1993) :

$$
\mathrm{C}=\Sigma(\mathrm{ni} / \mathrm{N})^{2}
$$

Dimana $\mathrm{C}$ adalah indeks dominansi spesies, ni adalah jumlah individu setiap spesies $i$, dan nilai $\mathrm{N}$ adalah jumlah total individu. Apabila nilai $\mathrm{C}<0.50$ maka tingkat dominansi jenis termasuk dalam kategori rendah, nilai $0.50<\mathrm{C}<0.75$ maka tingkat dominansi jenis dalam kategori sedang dan apabila $\mathrm{C}<0.75$ maka tingkat dominansi jenis masuk kategori tinggi.

Indeks Similaritas Sorensen (ISS) digunakan untuk melihat kemiripan spesies antar stasiun pengamatan rumus yang digunakan sebagai berikut :

$$
I S S=\frac{2 \mathrm{c}}{\mathrm{a}+\mathrm{b}} \times 100 \%
$$


Jurnal Laut Khatulistiwa, Vol. 3. No. 2 (Juli, 2020). Hal. 61-68.

Dimana ISS adalah Indeks Similaritas Sorensen (\%), a adalah jumlah genus yang ditemukan pada lokasi $\mathrm{a}, \mathrm{b}$ adalah jumlah genus yang ditemukan pada lokasi $b$, dan c adalah jumlah genus yang sama pada lokasi a dan b. Nilai ISS 75-100\% maka tingkat similaritas antara lokasi a dan b sangat mirip, nilai ISS 50-75\% maka tingkat similaritas masuk dalam kategori mirip, ISS 25-50\% masuk kategori tidak mirip dan nilai ISS $<25 \%$ masuk kategori sangat tidak mirip.

\section{Hasil dan Pembahasan}

Hasil identifikasi mikroalga epifit berasosiasi pada Sargassum sp. di perairan Desa Sepempang, Kabupaten Natuna terdiri dari 8 kelas, 36 ordo, 50 famili dan 65 genus. Dari total genus yang teridentifikasi, 39 genus termasuk dalam kelas bacillariophyceae, 8 genus kelas cholorophyceae, 4 genus kelas cyanophyceae, 6 genus kelas dinophyceae, 4 genus kelas zygnematophyceae, 1 genus kelas treboxiophyceae, 2 genus kelas

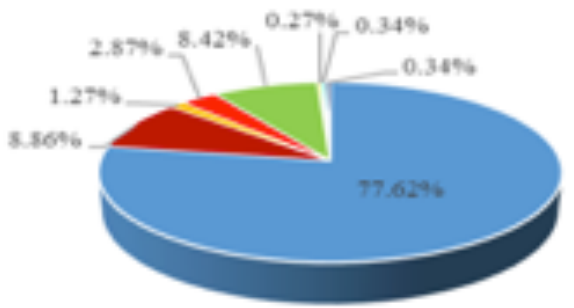

Stasiun I

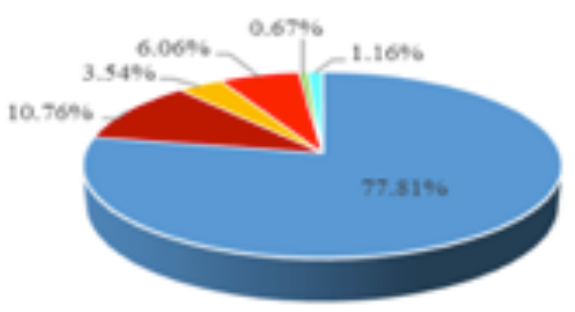

Stasiun III

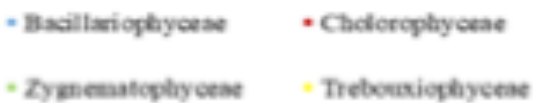

euglenophyceae dan 1 genus termasuk dalam kelas synurophyceae.

Kelas bacillariophyceae (diatom) adalah mikroalga yang mendominasi di semua stasiun penelitian dengan persentase kelimpahan (72.67\%), dimana kelimpahan diatom pennate sebesar $81.69 \%$ dan diatom sentris adalah 18.31\%. Dominasi kelas bacillariophyceae dikarenakan memiliki kemampuan dalam beradaptasi dengan perubahan lingkungan perairan. Selain itu, kelas Bacillariophyceae dapat menyesuaian diri dengan perubahan lingkungan yang ekstrim, memiliki pertumbuhan yang cepat, dan sering ditemukan pada setiap perairan sehingga dijadikan sebagai indikator biologis percemaran perairan (Putra et al., 2012; Arifin et al., 2015; Ismail, 2016). Diatom memiliki pertumbuhan cepat yang dipengaruhi oleh ketersediaan nutrien di perairan. Penambahan konsentrasi nutrien di perairan dapat mempengaruhi kelimpahan diatom, dimana lingkungan perairan Desa Sepempang banyak dipengaruhi oleh berbagai macam aktifitas manusia seperti pembuangan limbah rumah

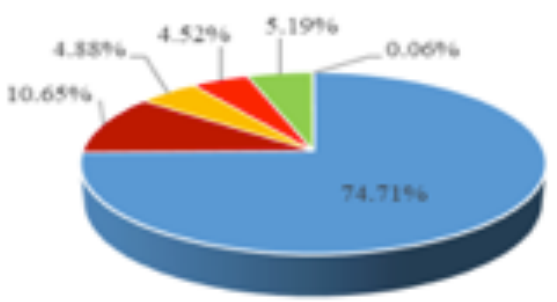

Stasiun II

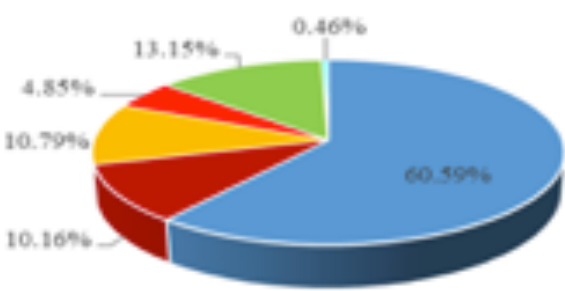

Stasiun IV

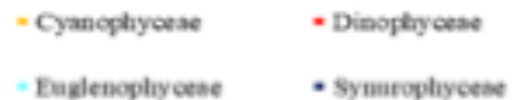

Gambar 2. Komposisi mikroalga epifit berdasarkan kelas di perairan Desa Sepempang 
Jurnal Laut Khatulistiwa, Vol. 3. No. 2 (Juli, 2020). Hal. 61-68.

Tabel 1. Indeks keanekaragaman ( $\left.\mathrm{H}^{\prime}\right)$, keseragaman (E) dan dominansi (C)

\begin{tabular}{lcccc}
\hline \multicolumn{1}{c}{ Indeks } & Stasiun I & Stasiun II & Stasiun III & Stasiun IV \\
\hline Keanekaragaman $\left(\mathrm{H}^{\prime}\right)$ & 3.07 & 3.07 & 3.18 & 3.04 \\
Keseragaman (E) & 0.77 & 0.83 & 0.83 & 0.78 \\
Dominansi (C) & 0.07 & 0.06 & 0.06 & 0.07 \\
\hline
\end{tabular}

Tabel 2. Indeks Similaritas Sorensen (ISS) di stasiun pengamatan

\begin{tabular}{cccc}
\hline Stasiun I & Stasiun II & Stasiun III & Stasiun IV \\
\hline Stasiun I & $80.85 \%$ & $84.00 \%$ & $82.69 \%$ \\
Stasiun II & & $87.80 \%$ & $75.55 \%$ \\
Stasiun III & & & $77.08 \%$ \\
Stasiun IV & & & \\
\hline
\end{tabular}

tangga dan budidaya ikan (Barokah et al., 2016). Purnawan et al. (2016), menyatakan bahwa kondisi perairan yang dangkal, kecerahan yang tinggi serta adanya masukan nutrien dari lingkungan sekitar memberi peluang untuk pertumbuhan diatom. Kelas bacillariophyceae juga memiliki alat perekat untuk menempel pada substrat thallus makroalga dan tumbuhan lainnya (Semary, 2016; Sarniati et al., 2017; Silalahi, 2001).

Pada lokasi penelitian, kelas bacillariophyceae memiliki komposisi tertinggi pada stasiun I (77.62\%) dan stasiun III (77.81\%) (Gambar 4.1), dimana stasiun I merupakan lokasi yang dekat dengan dermaga dan stasiun III merupakan area dekat dengan kegiatan budidaya ikan. Limbah budidaya seperti sisa pakan ikan, ekskresi biota budidaya dan feses berkontribusi secara signifikan terhadap kandungan nutrisi di perairan karena banyak mengandung senyawa anorganik nitrogen (N) dan fosfor (P) (Kautsky et al., 1997; Zhou et al., 2011), dimana $\mathrm{N}$ dan $\mathrm{P}$ merupakan sumber nutrisi bagi kehidupan mikroalga. Menurut Pello et al. (2014), kadar fosfat yang tinggi dapat mengakibatkan peningkatan populasi mikroalga di perairan khususnya kelas diatom.

Genus yang mendominasi dan dapat ditemukan pada setiap stasiun adalah Navicula, Nitzschia, Synedra, Cocconeis dan Pinnularia. Diatom mudah beradaptasi dengan lingkungan perairan, memiliki sifat toleransi yang tinggi terhadap perubahan lingkungan perairan dan dapat ditemukan pada setiap habitat. Nitzschia dan Navicula merupakan diatom yang bersifat soliter (Anil and
Mitbavkar, 2002). Tingginya kelimpahan Navicula dan Nitzschia dikarenakan kemampuan dalam beradaptasi dengan perubahan kondisi perairan dan memiliki alat gerak berupa tangkai gelatin sehingga dapat mempermudah pergerakan dan penempelan pada substrat (Kersen et al., 2011; Christiani et al., 2015; Al-Harbi, 2017). Menurut Suwartimah et al. (2011), Navicula cenderung mendominasi dan melimpah jika substrat mengandung nutrien tinggi dan penyedia makanan serta tempat pelindung dari organisme predator. Nitzschia merupakan genus yang sering ditemukan karena memiliki kemampuan dalam beradaptasi dengan perubahan lingkungan di sekitarnya. Menurut Israwati et al. (2018), Nitzschia adalah jenis mikroalga yang memiliki tingkat adaptasi yang tinggi dibandingkan dengan jenis mikroalga lainnya.

Selain bacillariophyceae, kelas chlorophyceae juga banyak ditemukan di Perairan Desa Sepempang. Chlorophyceae adalah organisme motil yang bersifat kosmopolit dan beberapa jenis dapat hidup melekat pada tumbuhan atau hewan. Selain itu, bentuk dan struktur tubuh chlorophyceae yang bervariasi dapat berupa motil, non motil dan filamen. Chlorophyceae dapat menghasilkan bahan organik dan oksigen, terutama berperan sebagai rantai makanan bagi ekositem akuatik. Selain itu, kelas ini juga berperan sebagai bioindikator kualitas perairan. Hal ini dikarenakan chlorophyceae memiliki tingkat toleransi terhadap perubahan lingkungan perairan seperti faktor fisika maupun kimia (Sagala, 2013). Kelas chlorophyceae 
Jurnal Laut Khatulistiwa, Vol. 3. No. 2 (Juli, 2020). Hal. 61-68.

berdasarkan hasil identifikasi banyak ditemukan pada stasiun III dengan persentase kelimpahan tertinggi sebesar $10.76 \%$, yang merupakan area dekat dengan budidaya ikan.

Kelas dinophyceae banyak ditemukan di Perairan Desa Sepempang dengan persentase kelimpahan tertinggi sebesar $4.85 \%$ di stasiun IV, dimana lokasi tersebut dekat dengan lokasi non aktifitas. Menurut Nitajohan (2008), dinophyceae dapat tumbuh menempel pada permukaan makroalga, lamun dan tumbuhan lainnya. Keberadaan dinophyceae dengan jumlah yang melimpah dapat mengakibatkan Harmful Algae Blooms (HABs) (HarnandezBecerril et al., 2012). Hal ini dilihat dengan perubahan warna pada perairan yang disebut dengan fenomena red tide.

Fenomena ini sering terjadi pada area dengan suplai nutrien berlebih (eutrofikasi) yang baik untuk pertumbuhan mikroalga (Faisal et al., 2005; Omura et al., 2012; Aprianti et al., 2015; Barokah et al., 2016). Menurut Nitajohan (2008), kelimpahan dinophyceae yang berlebihan di perairan dapat berdampak buruk bagi organisme laut, dimana dinophyceae juga dapat menghasilkan toksin yang menyebabkan kematian bagi organisme akuatik seperti ikan dan biota laut lainnya.

Synedra, Pinnularia dan Cocconeis memiliki jumlah kelimpahan tinggi dan persebaran yang merata antar stasiun. Genus Synedra memiliki tingkat toleransi yang tinggi sehingga mampu bertahan hidup dalam perubahan kondisi perairan yang ekstrim. Menurut Conradie (2008), Synedra memiliki sel pembungkus berlapis yang dapat dimanfaatkan sebagai pelindung tubuh. Sel Pinnularia dapat berbentuk linear, lanset dan bahkan berbentuk elips, dan Pinnularia dapat hidup pada sedimen dan substrat yang bercampur dengan gumpalan lumut (Harmoko, 2018). Selain itu, Synedra dan Pinnularia juga dapat bertahan pada kondisi perairan yang rendah nutrisi. Venter (2003) menyatakan jika Synedra dapat mengakumulasi nutrisi dengan menyimpan cadangan makanan dalam bentuk polimer yang tidak berlarut. Kelimpahan Synedra juga dapat dimafaatkan sebagai salah satu bioindikator perairan. Faktor lingkungan yang mempengaruhi kelimpahan Synedra di perairan yaitu suhu, salinitas, $\mathrm{pH}$, dan kecerahan.
Nilai indeks keanekaragaman $\left(\mathrm{H}^{\prime}\right)$ (Tabel 1) di Perairan Desa Sepempang berkisar antara 3.04-3.18 dan tergolong dalam kategori keanekaragaman tinggi. Nilai tertinggi ditemukan pada stasiun III dan terendah pada stasiun IV. Indeks keanekaragaman dapat mengambarkan kelimpahan epifit yang ada di perairan, selain itu keanekaragaman juga dapat dikaitkan dengan kondisi perairan.

Berdasarkan indeks Shannon-Winner nilai $H^{\prime}<1$ menunjukkan perairan dalam kondisi tercemar, untuk nilai $1<\mathrm{H}^{\prime}>3$ menunjukan kondisi perairan tercemar sedang dan nilai $H^{\prime}>3$ menujukkan bahwa perairan dalam kondisi tidak tercemar atau bersih. Berdasarkan kriteria tersebut, perairan Desa Sepempang tergolong dalam kondisi perairan tidak tercemar atau bersih.

Indeks keseragaman (E) menunjukkan sebaran mikroalga epifit dalam suatu komunitas. Perairan Desa Sepempang memiliki nilai indeks keseragaman dengan rentang antara 0.77-0.83 dan masuk dalam kategori keseragaman tinggi. Semakin tinggi nilai indeks keseragaman berarti sebaran jumlah individu setiap genus tersebut sama dan tidak ada genus yang mendominasi.

Indeks dominasi (C) digunakan untuk melihat ada tidaknya genus yang mendominasi di perairan. Nilai indeks dominasi di perairan Desa Sepempang berkisar antara 0.06-0.07 dan tergolong dalam kategori rendah. Rendahnya nilai dominasi berarti tidak ada genus yang mendominasi pada populasi mikroalga epifit di perairaan.

Indeks similaritas digunakan untuk menggambarkan perbandingan tingkat kesamaan spesies pada setiap stasiun. Nilai indeks similaritas di perairan Desa Sepempang berkisar antara 75.55-87.80\%. Nilai tertinggi terdapat antara stasiun II dan III yaitu $87.80 \%$ dan untuk nilai terendah antara stasiun II dan IV yaitu $75.55 \%$. Berdasarkan kategori menurut Odum (1993), stasiun II dan III memiliki tingkat similaritas sangat mirip. Hal ini diduga karena jarak antara kedua stasiun yang relatif dekat sehingga massa air saling bercampur. Selain itu, adanya masukan nutrien yang diperoleh dari limbah rumah tangga dan sisa pakan ikan, menjadi faktor utama kelimpahan mikroalga pada stasiun pengamatan. Persebaran mikroalga pada 
Jurnal Laut Khatulistiwa, Vol. 3. No. 2 (Juli, 2020). Hal. 61-68.

setiap stasiun juga sangat dipengaruhi oleh kecepatan arus.

\section{Kesimpulan}

Kesimpulan dari hasil penelitian adalah struktur komunitas yang ditemukan di perairan Desa Sepempang yaitu 8 kelas, 36 ordo, 50 famili dan 65 genus. Kemudian untuk kelas bacillariophyceae merupakan mikroalga yang mendominasi di perairan Desa Sepempang, Kabupaten Natuna.

\section{Daftar Pustaka}

Al-Harbi, S.M., and M.D.A. Affan. 2016. Seasonal Dynamics of Epiphytic Microalgae and Their Host Seaweeds Florideophyceae at Jeddah Coast, the Red Sea, Saudi Arabia, Pak. Journal Bot. 48(3): 1289-1298.

Al-Harbi, S.M. 2017. Epiphytic Microalgae Dynamics and Species Composition on Brown Seaweeds (Phaeophyceae) on the Northern Coast of Jeddah Saudi Arabia. Journal Oceanography and Marine Research. 5(1): 1-9.

Anil, A.C., and S. Mitbavkar. 2002. Diatom of the Microphytobenthic Community Population Structure in a Tropical Intertidal Sand Flat, National Institute of Oceanography. 140:41-57.

Aprianti, N.S., B. Sulardiono, and M. Nitisupardjo. 2015. Kajian tentang Fitoplankton yang Berpotensi sebagai HABs (Harmful Algal Blooms) di Muara Sungai Plumbon Semarang. Diponegoro Journal of Maquares. 4(3):132-138.

Arifin, S.M., Izmiarti, and Chairul. 2015. Komunitas Fitoplankton di Sekitar Sungai Utama di Zona Litorial Danau Singkarak Provinsi Sumatera Barat, Jurnal of Natural Science.4(3): 290-299.

Barokah, G.R., A.K. Putri, and Gunawan. 2016. Kelimpahan Fitoplankton Penyebab HAB (Harmful Alga Bloom) di Perairan Teluk Lampung pada Musim Barat dan Timur.

El-Din, S.G.N., N.A. Shaltout, M.Z. Nassar, and A. Soliman. 2015. Ecological Studies of Epiphytic Microalgae and Epiphytic Zooplankton on Seaweeds of the Eartern
Harbor, Alexandria, Egypt. American Journal of Environmental Sciences. 11(6): 450-473.

Christiani, A.; Insan, I., and Widyartini, D.S., 2015, Kelimpahan dan Potensi Biofuel Mikrofitobenthos dari Perairan Sungai Pekacangan yang Tekena Limbah Cair Topioka, J. Biosfera., 32(2):169-175.

Faisal, W., K.T. Basuki, and B.R. Sidharta. 2005. Studi Analisis Kista (CYST) Harmful Alga Bloom.

Harmoko, and Y. Krisnawati. 2018. Mikroalga Divisi Bacillariophyta yang Ditemukan di Danau Aur Kabupaten Musi Rawas, Jurnal Bio. UA. 6(1): 30-35.

Hernandez-Becerril, D.U, W.L.S. Lau, K.S. Hii, C.P. Leaw, F. Varona-Cordero, and P.T. Lim. 2018. Abundance and Distribution of the Potentially Toxic Thecate Dinoflagellate Alexandrium tamiyavanichii (Dinophyceae) in the Central Mexican Pacific, Using the Quantitative PCR Method, J. Frotiers in Marine Science. 5: 366. Doi: 10.3389/fmars.2018.00366

Ismail, J.S., 2016, Perifiton pada Daun Lamun Thalassia hemprichii dan Cymodocea Rotundata di Kampung Kampe Desa Malang Rapat, Tanjung Pinang. Skripsi. Riau : Universitas Maritim Raja Ali Haji.

Israwati, I.J. Effendy, and A.B. Patadjai. 2018. Komposisi Jenis dan Kepadatan Bentik Diatom pada Kolektor dan Kaki atau Otot Abalon (Haloitis asinina) yang Dipelihara di Kawasan Sistem IMTA (Integrated Multi Trophic Aqacuture) Out Door. Jurnal Media Akuatika. 3(1): 544-555.

Kautsky, N., M. Troell, and C. Folke. 1997. Biogical Engineering for Increased Production and Enviromental Improvement in Open Sea Aquaculture In: Etnier, C., Guterstam, B. (ads) Ecological Engneering For Waste Treament, $2^{\text {nd }}$ edn. Pp. 387-393, Lewis Publishers. Chelsea.

Kersen, P., K. Jonne, B. Martynas, K. Natalja, and D. Zane. 2011. Epiphytes and Associated Fauna on the Brown alga Fucus vesiculosus in the Baltic and the North Seas in Relation to Different Abiotic and Biotic Variables, Marine. Ecology. 32(1): 87-95. 
Jurnal Laut Khatulistiwa, Vol. 3. No. 2 (Juli, 2020). Hal. 61-68.

Martoni, P., A. Pratomo, and R.D. Putra. 2016. Identifikasi Mikroalga Epifit pada Daun Lamun (Enhalus acoroides) di Perairan Senggarang Kota Tanjungpinang. Skripsi. Riau : Universitas Maritim Raja Ali Haji.

Mottio, L., and C.E. Payri. 2010. Assessment of Five Markers as Potential Barcodes for Identifying Sargassum Subgenus Sargassum Species (Phaeophyceae, Fucules), Journal Cyptogamie Algol. 31: 467-485.

Nitajohan, Y.P. 2008. Kelimpahan Dinoflagelata Epibentik pada Lamun Enhalus acoroides (L.F) Royle dalam Kaitannya dengan Parameter Fisika-Kimia di Ekosistem Lamun Pulau Pari, Kepulauan Seribu Jakarta. Skripsi. Bogor : Institut Pertanian Bogor.

Odum, E.P. 1993. Dasar-Dasar Ekologi, Gajah Mada Univ Press, Yogyakarta.

Omura, T., M. Iwataki, V.M. Borja, Takayama, H., and Y. Fukuyo. 2012. Marine Phytoplankton of the Western Pacific. Kouseisha Kouseikaku Co., Ltd. Japan. 160pp.

Pello, F.S., E.M. Adwilaga, N.V. Huliselan, and A. Damar. 2014. Effect of Seasonal on Nutrient Load Input the Inner Ambon Bay. Bumi Lestari. 14(1): 63-73.

Putra, A.W., Zahidah, and W. Lili. 2012. Struktur Komunitas Plankton di Sungai Citarum Hulu Jawa Barat, Jurnal Perikana dan Kelautan.. 3(4): 3113-32.

Purnawan, S., I. Dewiyanti, and T.M. Marman. 2016. Bioteknologi Fitoplankton di Laguna Gampong Pulot (LGP) Kabupaten Aceh Besar. Jurnal Omni-Akuatik.. 12(2): 104112.

Rafaelina, M., Y. Rustam, and S. Amini. 2016. Pertumbuhan dan Aktifitas Antioksidan dari Mikroalga Prophyridium cruentum dan Chlorella sp. Jurnal Bioma. 12(1): 1-10.

Rindi, F., and M.D. Guiry. 2004. Composition and Spation Temporal Variability of the Epiphytic Macroalgal Assemblage of Fucus vesiculosus Linnaeus at Clare Island Mayo Western Ireland. Jurnal Expmenental Merine Biology and Ecology. 233-252.
Rosada, K.K., Sunardi, K.T.D. Pribadi, and S.A. Putri. 2017. Struktur Komunitas Fitoplankton pada Berbagai Kedalaman di Pantai Timur Pananjung Pangandaran. Jurnal Biodjati. 2541-4204 / 2548-1606.

Sagala, E.P. 2013. Dinamika dan Komposisi Chlorophyceae pada Kolam Pemeliharaan Ikan Gurame Berumur Satu Tahun dalam Kolam Permanen di Keluarahan Bukit Lama Kecamatan Hilir Barat Palembang, Jurnal Biologi Fakultas MIPA, Universitas Sriwijaya.

Sarniati, I.J. Effendy, A.M. Balubi, and A. Kurnia. 2017. Identifikasi dan Kultur Jenis Diatom Epifit dari Waring Keramba Budidaya Abalon. Jurnal Media Akuatika. 2(2): 377389.

Semary, N.A.E. 2016. Diatom as Bioindicators of Littoral Zone: A Case Study, Jurnal Bot. 45(5): 1113-1121.

Silalahi, S.M.C. 2001. Komposisi dan Kelimpahan Perifiton pada Terumbu Karang Buatan Bambu dan Ban Mobil Bekas di Perairan Tarahan, Bojonegera, Kabupaten Serang, Banten. Skripsi. Bogor : Institut Pertanian Bogor.

Suwartimah, K., Widianingsih, R. Hartati, and S.Y. Wulandari. 2011. Komposisi Jenis dan Kelimpahan Diatom Bentik di Muara Sungai Comal Baru Pemalang, Jurnal Ilmu Kelautan. 16(1): 16-23.

Venter, A., A. Jordaan, and A.J.H. Pieterse. 2003. Oscillatoria simplicissima : A Taxonomical Study School of Enivironmental Sciences and Development: Botany South Africa. Journal Water SA. 29(1): 101-104.

Zhou, H., C. Jiang, L. Zhu, X. Wang, X Hu, J. Cheng, and M. Xie. 2011. Impact of Pond and Fence Aquaculture on Resevoir Environment, Water Science and Engineering. 4(1): 92-100. 